\title{
Brakes on Chinese Development: Institutional Causes of a Growth Slowdown
}

\author{
Geoffrey M. HODGSON and Kainan HUANG
}

\author{
University of Hertfordshire Business School Working Paper (2012) \\ University of Hertfordshire Business School Working Papers are available for \\ download from https://uhra.herts.ac.uk/dspace/handle/2299/5549 \\ and also from the British Library: www.mbsportal.bl.uk
}

The Working Paper Series is intended for rapid dissemination of research results, workin-progress, and innovative teaching methods, at the pre-publication stage. Comments are welcomed and should be addressed to the individual author(s). It should be noted that papers in this series are often provisional and comments and/or citations should take account of this.

Copyright and all rights therein are retained by the authors. All persons copying this information are expected to adhere to the terms and conditions invoked by each author's copyright. These works may not be re-posted without the explicit permission of the copyright holders.

The Business School at the University of Hertfordshire employs approximately 150 academic staff in a state-of-the-art environment located in Hatfield Business Park. It offers 17 undergraduate degree programmes and 21 postgraduate programmes; there are about 80 research students, mostly working at doctoral level.

The University of Hertfordshire is the UK's leading business-facing university and an exemplar in the sector. It is one of the region's largest employers with over 2,300 staff and a turnover of £231million. In the 2008 UK Research Assessment Exercise it was given the highest rank for research quality among the post-1992 universities. It has a student community of over 27,000 including more than 2,900 international students. The University of Hertfordshire was awarded 'Entrepreneurial University of the Year 2010' by the Times Higher Education (THE) and ranks in the top 4\% of all universities in the world according to the latest THE World University Rankings. 


\title{
Brakes on Chinese Development: Institutional Causes of a Growth Slowdown
}

\author{
Geoffrey M. HODGSON ${ }^{1}$ and Kainan $\mathrm{HUANG}^{2}$
}

February 2012

\author{
1.University of Hertfordshire Business School, De Havilland Campus, Hatfield, Hertfordshire AL10 9AB, UK \\ www.geoffrey-hodgson.info \\ g.m.hodgson@herts.ac.uk
}

2.Center for Economic Research, Shandong University, Shanda Nanlu 27, Jinan, P. R. China 250100

KEY WORDS: China, development, institutions, demography, corporate law, land tenure

JEL classification: B52, J11, K22, O15, O16, O53

\begin{abstract}
China has enjoyed spectacular economic growth since the 1980s. Economic models based on production functions typically suggest that China's rapid growth will continue at similarly high rates, but they ignore pressing structural and institutional constraints on its development. Among the problems identified in this paper, we point to an impending demographic shift that will greatly increase the number of economic dependents, the inadequate corporate legal foundation for indigenous private enterprise, and the discriminatory, defective and disruptive system of land tenure. These problems suggest a pressing agenda of institutional reform to help China develop in future decades.
\end{abstract}




\title{
Brakes on Chinese Development: Institutional Causes of a Growth Slowdown
}

\author{
Geoffrey M. HODGSON and Kainan HUANG
}

After three decades of rapid growth, China is now poised to become the largest economy in the world. ${ }^{1}$ A great deal has changed since Mao Zedong died in 1976. Although Mao's regime greatly increased education levels and life expectancy, the economy suffered from the huge disasters of the Great Leap Forward and the Cultural Revolution. ${ }^{2}$ In December 1978, under the new leadership of Deng Xiaoping, the Third Plenum of the Eleventh National Congress Central Committee of the Communist Party announced a programme of modernization and reform to propel China in the twenty-first century.

Since 1978 China's economic growth has been spectacular. China's real GDP per capita has more than doubled in each of the three decades since 1980. From 1980 to 1990 GDP per capita grew at an average of 7.6 per cent per annum, from 1990 to 2000 this growth was 9.4 per cent, and in the first decade of the new millennium GDP per capita growth averaged 9.9 per cent per annum. In particular, the first decade of the twenty-first century has witnessed a huge structural transformation of China's industry and agriculture, affecting both the public and private sectors.

Many business reports behold a future of uninterrupted growth. One mainstream model of the Chinese macro economy estimates a Cobb-Douglas production function and has little difficulty predicting growth rates of around seven per cent well into the future (Chow and $\mathrm{Li}$ 2002). A later and more sophisticated model, likewise based on an estimated aggregate production function, similarly predicts unrelenting growth in Chinese total factor productivity (Song et al. 2011). Also on the basis of production function estimates, Nobel Laureate Robert Fogel (2010) has predicted that China's GDP will grow at an average rate of about 8 per cent until 2040, by which time its GDP per capita will be twice that in Europe and similar to that in the USA.

These models take inadequate account of the institutional and structural problems facing China today. A continuation of current high rates of growth is questionable, for several reasons, additional to the world economic slowdown after 2008. Much of the growth from

\footnotetext{
1 The authors thank Andrew Tylecote for comments on an earlier version of this essay.

2 In China from 1950 to 1965 life expectancy at birth did not rise above 44 per cent, but it rose steeply thereafter, reaching 66.3 per cent in 1975-80 and 70.8 per cent in 1995-2000 (UN Data 2012). The 1982 census showed that basic education was much more widespread than most low-income countries with 65.5 per cent having received formal schooling, with 34.7 per cent above primary level (Naughton 2007, p. 196). From 1950 to 1973 Chinese real GDP per capita grew at an average rate of 2.9 per cent.
} 
1980 to 2000 was powered by the rural sector, after the de-collectivisation of agriculture and the development of rural enterprises (Huang 2008). Further institutional changes are needed to address the problems of a rapidly-urbanising market economy. The brakes on future growth derive from a complex of institutional, structural and demographic factors. To alleviate the coming growth slowdown continue on a path of development, and avoid impending social instability, China has urgently to address an agenda of deep institutional reform.

China has many such problems, and we do not attempt a comprehensive survey of institutional constraints. Instead we focus on three broad structural and issues, namely (a) demographic shifts and the problem of supporting a larger dependent population, (b) the lack of a developed institutional and legal foundation for indigenous advanced private enterprise, and (c) the severe developmental constraints inherent in the existing system of land rights and residency registration.

The remainder of this paper is organised in five sections. The next section addresses the problems of Chinese demography and its growing educational and welfare needs. Section two examines the corporate sector in Chine industry and identifies severe inadequacies in the current system of corporate law. Section three addresses the rural land tenure system and the problems generated by the rural-urban divide. It identifies the land problem as a major and growing source of political instability in China. Section four sketches an agenda of institutional reform. Section five concludes the paper.

\section{Demographic and fiscal drag}

A major brake on China's future growth will be the changing age structure of the population and its impact on the fiscal and welfare system.

China's one-child policy was introduced in 1978 and has dramatically reduced the birth rate. It is estimated that in 2010 0-14 year-olds were 17.9 per cent of the overall population. At the same time, despite China's growth in the past three decades, factors including the underdevelopment of the health system have also resulted in a low proportion of seniors. It is estimated that in 2010 those of 65 years or more were 8.7 per cent of the overall population. Hence those of 15-64 years made up 73.4 per cent (US Census Bureau 2011). The 15-64 group is of working age and must generate most of the income and taxes to sustain the younger and older groups. The standard definition of the dependency rate is the sum of the percentages for seniors and children, divided by the percentage for the 15-64 years group. The dependency rate in 2010 in China was 36.2 per cent. This means that each person of working age must on average sustain 0.362 other people. This is much lower than most other countries at a similar level of development. But the situation is changing dramatically.

Demographic structures are major predictors of productivity and growth differences between nations and through time (Feyrer 2007). As they develop, countries often enjoy a 'demographic dividend' for a while, with low dependency rates. Around 2010 China had one of the lowest dependency rates in the developing world.

Demographic projections published by the US Census Bureau provide the raw data used to construct Figure 1. Such predictions can be inaccurate. The US Census Bureau assumes that fertility and mortality rates remain constant. On this basis, in 2030 China's dependency ratio will be about 48 per cent and rising, while India's will be at roughly the same level, after falling from much higher levels. By 2040 India and China will swap their 2000 positions, and China will have lost its current demographic advantage. 


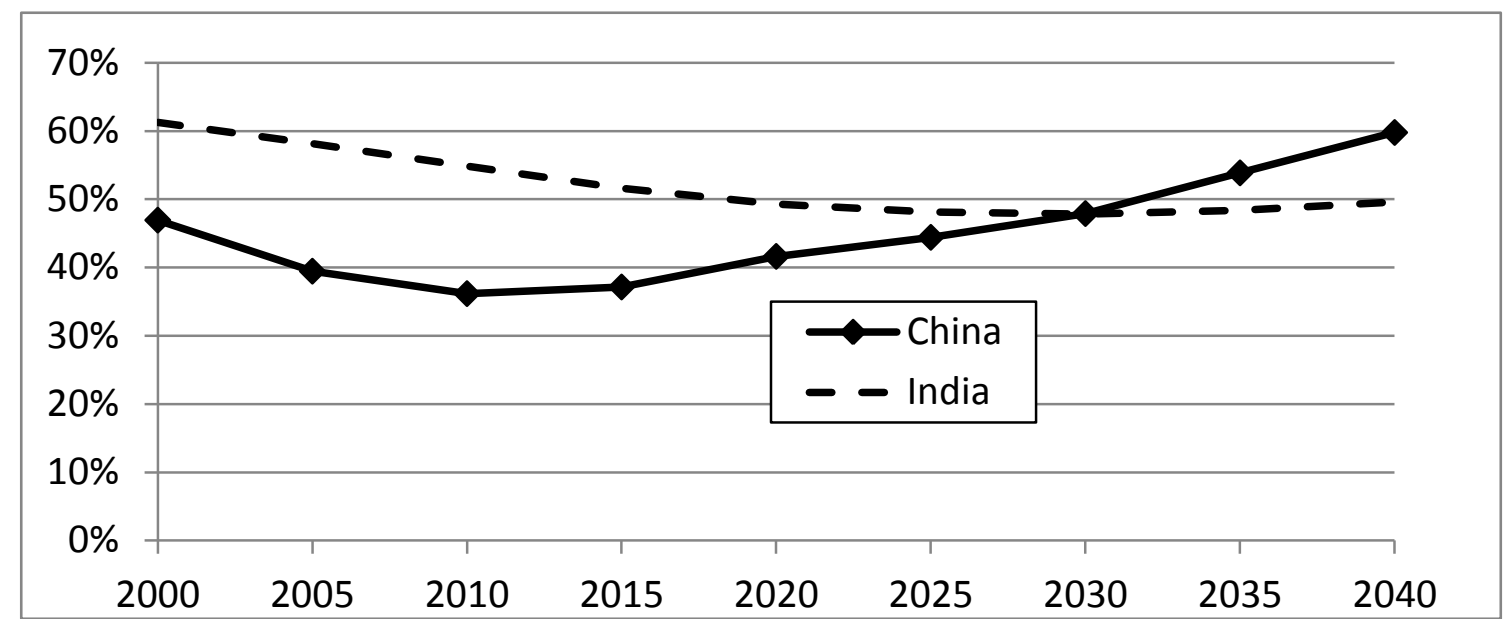

Figure 1: Dependency Rates in China and India

Calculated from data from US Census Bureau (2011)

But in China's case there are two strong forces pushing for an even further rise in the dependency rate than shown in Table 1 . The first is the potential future relaxation of the onechild policy. There are already cases where this policy does not apply, such as to ethnic minorities (registered at 8.49 per cent of the population in the 2010 census). In rural areas couples are sometimes allowed without redress to have a second child if the first is a girl. Today in many urban areas, if the couple are both children of a one-child family, then they are sometimes permitted to have two children. As many Chinese couples increase their incomes, some of the better-off opt to pay the fines for having a second child. There is currently a political debate concerning the one-child policy. If here the Chinese government liberalises, or makes concessions to enhance its popularity, then the one-child policy is likely to be relaxed or even scrapped. This would put additional upward pressure on the dependency rate, at least until the additional children became of working age.

China's population is aging at a relatively rapid rate. The percentage of seniors is expected to rise further, as China develops and its health services improve. This is the second source of upward pressure on the dependency rate. For all the above reasons, by 2030 it is likely that the dependency rate will increase to over 48 per cent and be over 60 per cent in 2040.

On the other hand, these demographic shifts would not make China's dependency rate larger than the norm in many developed countries. (Dependency rates in the USA are projected to reach about 80 per cent in 2030.) But no developed country is growing at anything like China's current breakneck speed. A growth slowdown in China seems inevitable, at least partly because of the fiscal strains imposed by these changes.

Before the 1980s reforms, central government received large revenues from surpluses from state-owned enterprises. Subsequent privatizations have reduced the size of that sector and the government has had to turn more and more to the taxation system for revenue. Revenues were 
falling until they reached a low level of 10.8 per cent of GDP in 1995. The 1994 deep reforms to the tax system dramatically reversed that trend.

By 2009 government revenue was 20.1 per cent of GDP and tax revenue was 17.5 per cent. The major components of the latter were value-added tax 5.4 per cent, business tax 2.6 per cent, consumption tax 1.4 per cent, tariffs 0.4 per cent, corporate income tax, 3.4 per cent and individual income tax 1.2 per cent. Hence tax income from individuals or their consumption amounts to a mere 8.0 per cent of GDP (National Bureau of Statistics of China 2011). There is also growing government indebtedness.

Partly powered by the demographic shifts outlined above, China's inadequate fiscal arrangements face growing challenges, including the need for welfare payments to unemployed and to the growing number of pensioners. Currently the pension system is urbanbiased, far from universal, and covers only a small fraction of the rural workforce.

By 2010, in 15 provinces the revenue from pension insurance funds was less than the required expenditure. Without major reform the pension system cannot survive without large financial subsidies (China Human Resources and Social Security Publishing Group 2011).

China's fiscal and social-security institutions are currently ill-equipped to deal with the projected rise in the dependency ratio. Without further dramatic reform and a big increase in tax rates, the population will have to fall back on traditional modes of supporting the old or infirm from within the family, thus restricting participation in the waged workforce by the 1564 age group.

Post-reform household saving rates in China are very high, reaching 33.7 per cent of income in 1994 and 23.6 per cent in 2000. This high savings rate reflects both the rapid recent growth in incomes and personal financial insecurity in the face of the underdeveloped social security system. Among the reasons for these high savings rates is to finance retirement (Modigliani and Cao 2004). Prudent as it may be for households, saving reduces aggregate effective demand for goods and services.

The Chinese government faces the pressing problem of reforming and expanding the pension and benefits system, alongside an equally urgent need to reform and expand its taxcollecting institutions. Dramatic tax increases are likely to be unpopular, unless the working population can be convinced that they are for their own future benefit. Ultimately, therefore, these problems are political, as well as administrative, economic and demographic.

A danger is that China will suffer a demographic 'Dutch disease', where the temporary advantages resulting from the one-child policy, and from the temporarily low proportion of seniors, lead the authorities to overlook the urgency of reforming and expanding the pension and social security system to deal with much higher dependency rates in the near future.

\section{Corporate impediments}

Much of China's economic growth from 1978 to 2000 emanated from the rural sector (Huang 2008). The de-collectivisation of agriculture and the development of some rural industry including the innovative 'town-village enterprises' (TVEs) - drove much of China's expansion in the 1980s and 1990s. But China has also become rapidly urbanised, and future economic growth will depend more on urban industry and services. In 1980, about 19 per cent of the population resided in urban areas. In 2010 the urban population was estimated at about 
47 per cent. ${ }^{3}$ Rural development remains important for China's growth, but it is no longer the principal engine of transformation. The organisational loci of growth have shifted from the rural townships and TVEs, to private and state-owned enterprises in urban areas. ${ }^{4}$

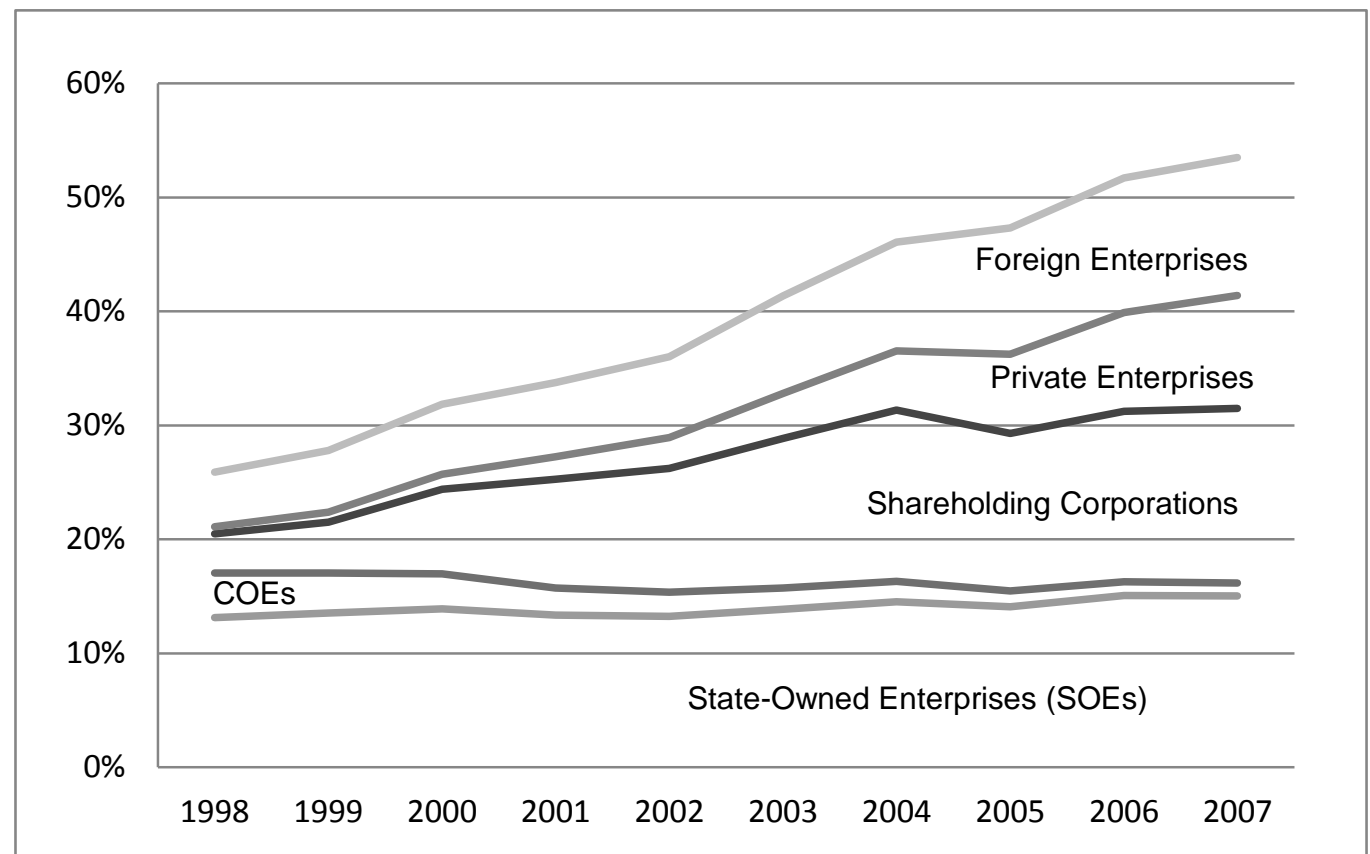

\section{Figure 2: Cumulative Percentage Contribution of Different Types of Industrial Enterprise to China's GDP}

Source: National Bureau of Statistics of China (2010)

Figure 2 shows the recent dramatic change, in the few years from 1998 to 2007, of the percentage contribution of different types of industrial enterprise to China's GDP. Enterprise contributions are measured in value-added terms. Note that the figures are cumulative: hence for example the 53.5 per cent overall figure in 2007 is the cumulative contribution of all types of industrial enterprise, not simply foreign enterprises.

In part these changes reflect a rapid growth of urban enterprise, but the growth of nonagricultural rural firms has remained important, and the proportions in the figure are not confined to urban areas. The figure shows the contributions of state-owned and state-holding industrial enterprises (SOEs), collective-owned enterprises (COEs), shareholding

\footnotetext{
3 The percentages are from Zhang and Song (2003) and Central Intelligence Agency (2011). All estimates are problematic because of the large number of (often temporary or unregistered) urban migrants from rural areas.

${ }^{4}$ Huang (2008) debunks much of the mythology surrounding TVEs and shows that they were typically private rather than collectively owned. From the mid-1990s, TVEs were forced to restructure. Many went bankrupt and some were expropriated by local officials. Rural industries today have taken on new forms and are often tied to local government.
} 
corporations, private enterprises, and foreign, Hong Kong, Macao and Taiwan enterprises. ${ }^{5}$ The residual proportion of GDP, which is mostly attributable to family farms, agricultural enterprises, and service sector enterprises, has shrunk from 74.1 per cent to 46.5 per cent in ten years. By contrast, the foreign, private and shareholding enterprises have markedly increased their portions of a rapidly-growing cake.

Consider the official definitions each type of enterprise in turn, according to the National Bureau of Statistics of China (2010). SOEs refer to a mixture of forms, principally stateowned enterprises, state-funded corporations, state-holding enterprises and state-owned jointoperation enterprises. With state-holding enterprises the percentage of state assets (or shares held by the state) is larger than any other single shareholder in the same enterprise.

COEs refer to non-state enterprises with collectively-owned assets. They include urban and rural enterprises with collective investments, and some registered cooperatives with pooled individual capital. The TVEs were placed in the COE category. Many COEs today are other kinds of rural enterprise owned by town and village committees. Of the five types of enterprise considered here, COEs are the least important and their GDP share has declined markedly.

Shareholding corporations are registered joint-stock units with their capital divided into shares. They include both private limited companies and limited companies with public shares on the stock market. The legal liability of investors is limited to their shareholding. The 2005 Company Law requires that minimum amount of the registered capital of a joint stock limited company is RMB 5,000,000 and that at least half of the company sponsors are domiciled in China. The corporation must apply to the Securities Regulatory Authority under the State Council for permission to issue its shares on the stock market.

Private enterprises refer to registered economic units owned by individuals. Included in this category are small private limited liability corporations, private partnerships and private sole investment enterprises.

Foreign enterprises refer to companies registered as having funds from Hong Kong, Macao, Taiwan, and elsewhere outside China.

Figure 2 shows that the most important changes in 1998-2007 were the growing shares of China's GDP attributable to foreign, private and shareholding enterprises. These forms of enterprise seem to be taking the dynamic lead. But this would be a superficial judgement, for several reasons. To get a better picture we need to look at some further data.

Table 1 reveals some additional features and some major transformations. Note first the growth in the average size of SOEs, the small and declining size of COEs, and the relatively small size of private enterprises.

The 2010 clear leaders, both in terms of average size and output per worker, were the SOEs and the shareholding corporations. Yet in Figure 2 the share of GDP attributable to SOEs showed only a slight increase from 1998 to 2007. This is a result of many closures and privatisations, and a huge shakeout of labour from SOEs from 1993 to 2007 (Naughton 2007, pp. 106-7, 185-6, 300-1). It was mostly the small and loss-making SOEs that were privatized (Huang 2008, p. 169). Of the SOEs in existence in 1998, only 31.3 per cent of these enterprises were surviving in this sector in 2010. In 1998 about 37.5 million workers were employed in SOEs. This fell to a low of 17.4 million in 2007 , but rose slightly to 18.4 million

\footnotetext{
${ }^{5}$ Henceforth foreign, Hong Kong, Macao and Taiwan enterprises are simply referred to as 'foreign enterprises'.
} 
in 2010. Surviving SOEs reformed organisationally and were granted more autonomy, while retaining state ownership. ${ }^{6}$

\begin{tabular}{|c|c|c|c|c|c|c|c|c|c|c|}
\hline & \multicolumn{2}{|c|}{ SOEs } & \multicolumn{2}{c|}{ COEs } & \multicolumn{2}{c|}{$\begin{array}{c}\text { Shareholding } \\
\text { Corporations }\end{array}$} & \multicolumn{2}{c|}{$\begin{array}{c}\text { Private } \\
\text { Enterprises }\end{array}$} & \multicolumn{2}{c|}{$\begin{array}{c}\text { Foreign } \\
\text { Enterprises }\end{array}$} \\
\hline & $\begin{array}{c}\text { Mean } \\
\text { number } \\
\text { of em- } \\
\text { ployees }\end{array}$ & $\begin{array}{c}\text { Mean } \\
\text { real } \\
\text { output } \\
\text { per } \\
\text { employee }\end{array}$ & $\begin{array}{c}\text { Mean } \\
\text { number } \\
\text { of em- } \\
\text { ployees }\end{array}$ & $\begin{array}{c}\text { Mean } \\
\text { real } \\
\text { output } \\
\text { per } \\
\text { employee }\end{array}$ & $\begin{array}{c}\text { Mean } \\
\text { number } \\
\text { of em- } \\
\text { ployees }\end{array}$ & $\begin{array}{c}\text { Mean } \\
\text { real } \\
\text { output } \\
\text { per } \\
\text { employee }\end{array}$ & $\begin{array}{c}\text { Mean } \\
\text { number } \\
\text { of em- } \\
\text { ployees }\end{array}$ & $\begin{array}{c}\text { Mean } \\
\text { real } \\
\text { output } \\
\text { per } \\
\text { employee }\end{array}$ & $\begin{array}{c}\text { Mean } \\
\text { number } \\
\text { of em- } \\
\text { ployees }\end{array}$ & $\begin{array}{c}\text { Mean } \\
\text { real } \\
\text { output } \\
\text { per } \\
\text { employee }\end{array}$ \\
\hline 1998 & 579 & 25.2 & no data & no data & no data & no data & 151 & 36.4 & 293 & 60.8 \\
\hline 2004 & 554 & 88.2 & 688 & 38.1 & 659 & 120.1 & 127 & 57.5 & 293 & 93.2 \\
\hline 2010 & 907 & 189.3 & 189 & 102.9 & 644 & 193.7 & 121 & 120.5 & 357 & 134.3 \\
\hline
\end{tabular}

\section{Table 1: Size and Output per Employee by Different Types of Industrial Enterprise}

Sources: National Bureau of Statistics of China (2004, 2006, 2010, 2011). Mean real output per employee is in 1,000 RMB per annum in 1978 prices.

The focus of surviving SOEs is within large-scale manufacturing industry, where increasing returns to scale are typical. Much of the production of industrial materials and energy is within SOEs. Most large-scale civil construction, including roads, bridges and the ambitious high-speed railway system is being performed by large SOEs. The four largest indigenous automobile companies in China - SAIC Group, Chang'an Motors, FAW Group, and Dongfeng Motor - are SOEs. China Mobile is a massive state-owned mobile-phone company with $600 \mathrm{~m}$ customers. Three Chinese state-owned companies rank among the world's ten biggest companies by revenue (Economist 2012).

SOEs benefit more than other enterprises from state favouritism and state industrial policies (Huang 2008, pp. 169-70). There is also evidence that SOEs have relatively easier access to finance from the largely-state-owned Chinese banks (Boyreau-Debray and Wei 2005). The SOEs also received a large financial boost from the 2008-2009 four trillion RMB (US\$ 586 billion) stimulus package to mitigate the effects of the world economic and financial crisis. Although this package helped enterprises of all types, SOEs benefitted especially as a result of its large-scale industrial and infrastructural features. In 2009 some 85 per cent of China's $\$ 1.4$ trillion in bank loans went to SOEs (Economist 2012).

Increased efficiency is manifest in the sector as a whole. Output per worker in the SOE sector has increased by a huge factor of 7.5 from 1998 to 2010, making average output per

\footnotetext{
${ }^{6}$ Nolan and Xiaoqiang (1999, p. 169) pointed out that SOEs were 'not stagnant fossils waiting to die ... this sector has undergone large change due to enhanced enterprise autonomy, the impact of market forces, rapid growth of domestic demand for upstream products, strategic integration with the world economy and the state's policy to promote large businesses.'
} 
worker in SOEs comparable to that in private shareholding corporations. Summary statements that SOEs are 'less productive' (Song et al. 2011, p. 208) or have 'lower productivity' (OECD 2011, p. 13) are out of date, at least in terms of gross output per employee. The overall productivity increase in the SOE sector is astounding. But these gains are largely due to the elimination of the less efficient from this sector. The gains in productivity of individual SOEs are much less impressive. Although surviving SOEs perform as well as many private firms, questions arise concerning future improvements in SOE productivity, especially if SOEs were to operate alongside other types of enterprise on a more level playing field. Further large productivity improvements gained by culling the less efficient from this sector may also be more difficult to achieve. ${ }^{7}$

Figure 2 above shows that the fractional contribution of industrial SOEs to China's rapidlygrowing GDP grew very slightly from 1998 to 2007. This means that industrial SOE output grew slightly faster than China's GDP as a whole. But the contribution of SOEs to China's export performance has declined in fractional terms. The share of China's exports produced by SOEs fell dramatically from 66.7 per cent in 1995 to 19.7 per cent in 2006 (Wang and Wei 2008, Table 2). Other forms of enterprise now account for the lion's share of China's exports.

We turn to non-foreign, private and shareholding enterprises. These account for rapidly rising shares of China's GDP. Shareholding enterprises are on average much larger than firms categorised as private enterprises. Shareholding industrial enterprises were responsible for 3.5 per cent of GDP in 1998 and 15.3 per cent in 2007. Private industrial enterprises were responsible for 0.6 per cent of GDP in 1998 and 9.9 per cent in 2007. In ten years, industrial private and shareholding firms together have grown from about 4 per cent to about a quarter of Chinese GDP. They have also made impressive gains in output per worker, without relying on the culling effect observed in the SOE sector.

On the other hand, their export performance has been less impressive. While private and shareholding industrial firms made up about 23.6 per cent of GDP in 2006, their share of exports was 17.8 per cent. While the 2006 export-share of SOEs was still higher than their share of GDP, the export-share of private and shareholding enterprises was significantly lower than their GDP-share. Yet by conventional wisdom, this young and dynamic private sector should be at the vanguard of China's export performance. Business writers such as Donald N. Sull (2005) extoll the 'trailblazing' performance of private firms in China. In fact, private and shareholding Chinese firms are punching below their weight in export markets.

By contrast the foreign firms in China have a higher export share than share of GDP. China joined the World Trade Organisation in 2001 and this opened the door further for foreign direct investment. Overall, the share of China's exports produced by foreign-owned firms increased from 11.7 per cent in 1995 to 39.5 per cent in 2006. (Wang and Wei 2008, Table 2). From 1998 to 2006, their contribution to China's GDP increased from 4.8 to 11.8 per cent. The role of foreign firms in the contemporary Chinese economy is ironically redolent of the pre-1949 colonial period when foreign concessions in Hong Kong, Shanghai and elsewhere were China's trading gateway to the outside world.

What is happening to prevent the growing domestic private firms exporting at levels comparable to their share of GDP? Part of the problem is that private and shareholding enterprises have insufficient access to finance to invest in international marketing and exports.

\footnotetext{
7 There is evidence that local SOEs supplying foreign firms in China benefit from substantial spillover productivity gains (Du et al. 2011). But foreign invested firms in China tend to have a relatively low share of domestic value-added content in their exports (Koopman et al. 2008).
} 
Also the private and shareholding enterprise sectors have not yet developed sophisticated forms of corporate organisation and governance. In the absence of adequate legal measures of contract enforcement, much private enterprise is reliant on trust relations generated through extended family and personal ties (Boisot and Child 1996, Wank 1999). Although there were major reforms to corporate law in China in 1994 and 2006, the legal security of company investments and the fair enforcement of existing company legislation remain matters of concern for both businesses and the political authorities. Many functioning Chinese firms lack an adequate legal foundation, creating problems of contract enforcement, legal liability and enterprise accountability (Clarke 2005). High levels of public and private corruption in China undermine the proper functioning of public administration and the legal system and create further impediments to fair competition. ${ }^{8}$ The financial, organisational and legal structures required to support private exports are highly underdeveloped and they are holding back China's export growth. Unfortunately, the required institutional changes will inevitably be slow and difficult to achieve.

As Peter Nolan (2004, p. 20) points out: 'The blunt reality is that after two decades of reform China's large firms are still far from being able to compete with the global giants. The gap is especially marked in the high-technology sectors'. Barry Naughton (2007, p. 325) notes similarly that 'so far China has produced only a handful of firms that approach international best practice in corporate governance. The firms on everyone's short list include Lenovo the computer company; a few telecommunications equipment firms, Huawei and ZTE; and a few producers of consumer durables such as Hai'er.' But this 'short list' reveals another matter of concern. None of the four firms mentioned by Naughton is typical of the Chinese private enterprise sector in terms of shareholding or corporate registration.

Listing several Chinese corporate 'trailblazers', Sull (2005) wrongly describes Lenovo, Sina, UTStarcom, AsiaInfo, Hai'er, Galanz, Wahaha and Ting Hain as straightforwardly Chinese enterprises. The facts are different (Huang 2008, pp. 1-12). Lenovo is registered in Hong Kong, not in mainland China, and is thus subject to a British-derived system of corporate law. Huawei has an opaque ownership structure and is subject to defence-related secrecy. Hai'er is not itself a foreign company but its main business and production subsidiaries are abroad. ZTE is a Chinese company but it is registered in Shenzhen, which is a partly autonomous Special Economic Zone with a more business-friendly legal and financial environment. Leading 'Chinese' firms such as Sina, UTStarcom, Ting Hain and AsiaInfo are wholly owned foreign investor enterprises. With Galanz and Wahaha their main business and production subsidiaries are foreign. As Naughton (2007, p. 417) notes: 'Of the top ten firms in China exporting high-tech products in 2003, nine are foreign - four from Taiwan and five from the United States.'

Domestic hi-tech firms have performed less well. For example, the Great Wall Group operated within China's domestic business environment but 'foundered badly' (Huang 2008, p. 5). Financial resources for private business are scarce, and the role of the domestic stock market in generating capital and allocating resources in the economy has been 'limited and ineffective' (Allen et al. 2008). ${ }^{9}$

\footnotetext{
${ }^{8}$ See Manion (1996), Kwong (1997), He (2000), Lu (2000) and Nolan (2004, pp. 40-44) on corruption in China, and Hodgson and Jiang (2007) for a more general discussion.

${ }^{9}$ As an exception that proves the rule, the China-based private solar panel company Suntech Power has successfully established a global presence. But its founder Shi Zhengrong acquired Australian citizenship before returning to China in 2001 to establish the firm.
} 
Crucially, outside registration gives more autonomy and more reliable legal protection for many leading 'Chinese' private firms. ${ }^{10}$ Otherwise, many dynamic and seemingly private firms in China are still part-owned or controlled by the state: 'By the end of 2004 there were 1,377 firms listed on the markets in Shanghai and Shenzhen, most of them were still government controlled' (Naughton 2007, p. 469). Control and ownership structures in China are so complex that it is difficult to disentangle the public from the private. There is a plethora of business types, including nationally-owned, local government owned, nationally controlled private, local government controlled private, and privately owned and controlled, firms (Huang 2008, pp. 13-26). Many successful 'private' firms in China are foreign-owned or state-controlled. The contribution of genuinely private Chinese firms is much less than it appears at first sight. Part of the problem is the lack of adequately developed legal and other institutions to support independent private enterprise.

Firms operating in China but legally registered in Hong Kong, Macau or Taiwan are the stars of China's export performance. We have noted that the share of China's exports produced by foreign-owned firms increased spectacularly in a few years to reach 39.5 per cent in 2006, while their contribution to China's GDP was 11.8 per cent in that year. One author describes China as a Leader of the World Economy (Chow 2011). China's economic performance is stunning. But in terms of the development of corporate governance and corporate law, which are necessary for future development with a secure and innovative private sector, China remains a poor follower rather than a global leader.

\section{Land institutions and the rural-urban divide}

In December 1978, in the same month of the reforming Third Plenum, farmers from 18 households in Xiaogang village in Anhui Province secretly adopted a system where each household would take responsibility for its own parcel of land and take ownership of its outputs (Zhou 1996). Although the Third Plenum did not propose the de-collectivisation of agriculture, the new climate of reform encouraged illegal experimentation with the new 'household responsibility system' (baochan daohu). The results of this new system were so astonishing that a national decision was reached in 1980 to legalise the household responsibility system in the poorest communes. The gains in output and incomes were so spectacular that it was impossible to prevent the spread of the new system. Most agricultural communes had disappeared by the end of 1983. China's agriculture was de-collectivized.

This single reform, triggered by changes at the top but powered by pressure from below, transformed Chinese agriculture, brought millions out of destitution and set the country on its post-1980 path of rapid development.

But the rural land was still owned by the village collectives, and remains so to this day. Although agricultural de-collectivisation radically altered China's economic fortunes, institutional residues of the collectivist period still have profound and sometimes deleterious effects on China's economic and social development.

10 The Constitution of the People's Republic of China (2004) states in its Article 11 that: 'The State encourages, supports and guides the development of the non-public sectors of the economy and, in accordance with law, exercises supervision and control over the non-public sectors of the economy.' Effective compliance with this Article depends crucially on the fair and constrained application of the law. Lack of trust in the legal system may raise concerns regarding overly-intrusive or inappropriate 'supervision and control' of the private sector. 
The Chinese government has made the development of rural areas and remote regions a priority. To some extent these policies have been successful, particularly through the extensive development of transport infrastructure. But huge regional inequalities and a large urban-rural gap remain (Sicular et al. 2007).

The gap between urban and rural areas and their inhabitants is institutionalised in the household registration system (hukou). Redolent of residence permits in ancient China, this system was developed in the 1950s during the launch of the command economy, primarily to control the movement of labour between rural and urban areas. According to the hukou system, every Chinese citizen has a registered principal residence and a registered status as a rural or urban citizen (Chan and Zhang 1999). Against Article 33 of the Constitution of the People's Republic of China (2004), which declares that all citizens 'are equal before the law', the hukou system divides the Chinese population into two classes, according to registration at birth. Urban and rural citizens have different rights and entitlements. It is possible but difficult to change from rural to urban status. Hukou segregation is near-indelible.

Apart from controlling population movements, the hukou system obliged rural residents to work in the agricultural collectives. After de-collectivisation in the 1980s, this obligation was converted ostensibly to the right to use land, which is owned and allocated by village committees. From 1988, systems of election of village committees were established in many provinces, marking a significant extension of local democracy (Wang 1998). Through the village committees, rural registrants often have land-use rights that are not extended to urban registrants. On the other hand, urban registrants are entitled to the better-paid jobs, education, housing, and healthcare, most of which are unavailable to those with rural registration. The hukou remains as one of the most important determinants of differential privilege and social stratification.

Some relaxations of the hukou system have been introduced since 1980. By the 1990s it became possible for rural residents to buy temporary urban residency permits, thus giving the option to work legally for a while in the cities. Further reforms in the first decade of the new millennium were interpreted by some as a dismantling of the system. In fact they amounted to a devolution of responsibility for hukou administration to local governments, which can make permanent migration of peasants to cities harder than before (Chan and Buckingham 2008).

The hukou system is put under strain by growing Chinese urbanisation and the transformation of the rural areas. The modernisation of farming practices, land seizures by the state, and the closure of inefficient SOEs and COEs in rural areas, have left a huge rural population looking for work. Furthermore, the wide discrepancy between rural and urban incomes has spurred rural workers to move to the cities.

Consequently China is now experiencing the largest mass migration from the countryside to the cities in any country in history. An estimated 230 million Chinese - about 17 per cent of the entire population - have migrated to the cities in recent years. The number is expected to surpass 300 million by 2025 (China Labour Bulletin 2011). But this is no ordinary developmental migration. The migrants are registered second-class citizens in their own country, with inferior access to education and healthcare, and no indefinite rights of urban residence.

Migrant workers are usually given labour-intensive, low-skill jobs. The rapidly-expanding Chinese cities provide many opportunities for work on construction sites and heavy industry. But this relatively uneducated and unskilled workforce is unsuited for cutting-edge jobs in a growing knowledge-intensive economy. Because of their migrant status there are lower incentives for firms to invest in the development of their skills. Under current institutional 
arrangements, few of these migrants attain post-elementary educational qualifications. As rural registrants, they typically retain a rural orientation and a desire to send money back to their family and relatives in their village. The institutionalisation of their inferior status denies the Chinese economy access to an enormous source of potentially skilled labour and entrepreneurial drive.

In the rural areas the hukou system is coming under severe strain. Rural development, rural industry and rapid urbanisation eat into the available agricultural land, displacing many more rural residents. To understand the institutional constraints we first need to consider the legal and constitutional situation in more detail. A relevant extract from the Constitution of the People's Republic of China (2004) reads as follows:

Article 10. Land in the cities is owned by the state. Land in the rural and suburban areas is owned by collectives except for those portions which belong to the state in accordance with the law ... The State may, in the public interest and in accordance with the provisions of law, expropriate or requisition land for its use and shall make compensation for the land expropriated or requisitioned. No organization or individual may appropriate, buy, sell or otherwise engage in the transfer of land by unlawful means. The right to the use of land may be transferred according to law....

The rural collectives distribute land-use rights to local farmers. The collectives are responsible for monitoring land use, and have the power to allocate land for housing and local industry, as well as agriculture. Furthermore - under Article 10 - the state has the right to expropriate or requisition land from rural collectives 'in the public interest'. Major problems here are that the compensation level is very low, there is no clear definition provided of 'public interest' in this rural context, and the legal means to challenge a land expropriation are extremely limited. ${ }^{11}$

The increasing frequency of land seizures and the limited legal means to protect local land rights from the over-extended ambitions of local government officials, have led to a growing tide of rural protest. Estimates of the number of protests and demonstrations in China vary, but they have increased dramatically in number since 2000. Some estimates in 2005 put the numbers at around 200 such protests daily in urban areas, and roughly 100 daily in villages (Economist 2005). Researchers from the Chinese Academy of Social Sciences report that disputes over land account for 65 per cent of what are officially termed 'mass conflicts'. 73 per cent of petitions and complaints filed by farmers are related to land. Problems with low compensation and unsatisfactory resettlement are the main point of discontent. In particular, the report notes that that some local authorities have been grabbing land occupied by rural houses on response to a central government order to set aside arable land to help ensure food security. Many thousands of farmers, whose families have lived in farmhouses for generations, are being relocated to multi-story buildings so that local governments can sell the land to developers for profit (Bian 2005).

One of the most serious internal disturbances in China since 1949 was in the large coastal village of Wukan in Guangdong province in late 2011. Residents of Wukan petitioned the national government in 2009 and 2010 over land seizures. Large-scale protests began in September 2011 after corrupt local officials sold land to real-estate developers without properly compensating the farmers. Mass demonstrations led to violent clashes between the locals and the police. The authorities allowed the protesters to select 13 representatives to engage in negotiations. But five of these were taken into custody where one died. This

${ }^{11}$ See Land Administration Law of the People's Republic of China (2004), articles 2, 4. 10, 12 and 47. 
sparked an uprising on 14 December. The villagers forced all Communist Party officials and police to flee the area. The village was put under siege by the police and food supplies were cut off. On 20 December senior provincial officials intervened in the dispute and acknowledged farmers' basic demands. An investigation was set up. The villagers demanded the return of their farmland, the publication of the village committee's financial records, and a re-election of the committee. The provincial officials admitted to mistakes in handling the grievances and vowed to crack down on corruption. ${ }^{12}$

On 28 December 2011, in a statement at a national conference on rural affairs, the Chinese Premier Wen Jiabao called on local officials to better protect the rights of farmers and ensure they receive a bigger share of profits from the conversion of land to industrial and residential use (Zheng 2011).

Rural China is in a severe and growing crisis, exacerbated by anachronistic institutions, growing pressures of urbanisation, poor standards of local governance, and corrupt local officials benefitting from the increased value of land. Major grievances are fuelling rural discontent. Apart from the threat to social and political stability, the hukou system excludes much of the Chinese population from adequate education and health services. The Chinese economy is thus deprived of millions of potentially skilled workers. Increasing demands on the limited supply of suitable land have increased its value, enlarged opportunities for local corruption, and undermined the fragile rule of law in rural areas.

Although agricultural productivity has increased enormously since the 1970s, farming output has to be further increased to deal with a growing and more prosperous population under the constraint of a limited supply of suitable agricultural land. The existing land tenure system does not do enough to facilitate productivity-enhancing investment in modern agricultural technology.

Fernando De Soto (2000) and others have proposed the use of land as collateral for financial loans, which in turn can be used for agricultural improvements or creating local businesses, to promote rural development. Land collateralisation requires a secure system of registration and property rights. Efforts in this direction in other countries have led to some positive results, although collateralisation also depends crucially on viable and accessible banking and legal institutions. China's current land institutions cultivate corruption rather than the productive collateralisation of rural assets. These anachronistic institutions are brakes on development. In the next section we propose reforms that would permit substantial collateralisation, without challenging the constitutionally-enshrined state and collective ownership of the land.

\section{An agenda for institutional reform}

We propose a series of institutional reforms to address the problems raised in preceding sections of this essay. We start with the problems of land reform and the hukou system.

For reasons of both economic development and human rights, we propose that the hukou system should be abolished. Residence rights, and rights to access education and healthcare, should be equal for all Chinese citizens. There should be no discrimination on the grounds of ethnicity or place of birth. The hukou system is an unwarranted hangover of China's ancient

\footnotetext{
12 See BBC (2011), Huang (2011) and other sources from Wikipedia (2011).
} 
history and collectivist past. It is a massive institutional constraint on education and the development of workforce skills.

Abolition of the hukou system raises the problems of the distribution of land-use rights among the population and the retention of a viable rural workforce. These problems can be resolved by a one-off distribution of tradeable land leases in return for current land-use rights. This initial distribution of leases would be free of charge to rural registrants in the first instance only. A move in this direction has been proposed by the Organisation for Economic Cooperation and Development (2011, p. 17):

The underlying ownership of the land could remain with the collective but smallholders should be allowed to have ownership rights that are similar to those offered to urban residents. In particular, they should be entitled to fully transferable use-rights to their land that would be inviolable for a period of 70 years. With more secure tenure, the average farm household (which currently possesses use-rights for 0.6 hectare of farmland and 0.06 hectare of residential land) would have considerable assets. In order for farmers to make long-term, productivity-enhancing and income-generating investments on land, enhanced access to medium or long-term credit is key and so farmland use-rights should become mortgageable. With well-enshrined rights, farmers would also receive better compensation when the government acquires their land-rights by using the compulsory acquisition laws.

This OECD statement is welcome but inadequate in terms of crucial detail. It does not call explicitly for the abolition of the hukou system, but that is a necessary concomitant of adequate land reform. After taking possession of the land-lease, rural families should acquire the same status and equivalent rights of urban registrants. Their land-use rights would then be a result of their leasehold tenure rather than their former status as rural registrants. This explicit transformation is vital to make the leasehold market work properly and to clarify the practical basis of the system. Abolition of the hukou divide and the acquisition of tradeable land leases are thus simultaneous operations.

It also needs to be emphasised that rural workers should acquire the same access to the education and health systems as other citizens, with the important economic consequence of greatly widening the development of a skilled and healthy workforce. The OECD proposal is explicit about the mortgageability of land-leases, but more needs to be said about the development of suitable legal and financial institutions to make mortgaging viable and secure.

The final sentence of the quoted OECD proposal is particularly underdeveloped. Under existing regulations, the provisions for compensation after compulsory government acquisition are severely inadequate and insecure. These current regulations have to be changed to enshrine compensation at a level equivalent to the market value of the land lease. This in turn implies a fully tradable land lease system, protected by viable legal institutions with vastly reduced levels of nepotism and corruption. Without these institutional conditions, the rights of farmers and rural residents cannot be adequately protected. Crucial here is the general ongoing reform of the legal system and we return to this point later.

After the installation of tradeable land leases, village committees would retain the important role of supervision of the land-lease system. Possession of a land lease would carry the existing constitutional requirement that the land is used effectively and in the public interest. If a rural family wishes to move elsewhere and abandon the land, then they would be required to sell the lease to the village committee or another buyer. General leasehold saleability could lead to some concentration of land ownership and the development of agricultural corporations or cooperatives. Along with the mortgageability of land leases, some 
concentration of leasehold tenure will facilitate investment in agricultural technology and lead to economies of scale. At the end of the period of the lease (say 70 years) the user rights would return to the village committees, who would then sell a renewed 70-year lease on the rural property market.

Turning to the problems of corporate reform, a key issue here is the promotion of indigenous Chinese enterprise. As noted above, the home-grown private corporate sector in China is remarkably underdeveloped. This weakness is largely attributable to the recent development of a private sector, a relatively young and primitive legal system and the lack of a history of corporate legal security. Corporations registered in mainland China require secure rights to minimise fears of illegitimate state interference, punitive taxation or uncompensated nationalisation. Such institutions did not develop in the West until a form of state emerged with adequate checks and balances and countervailing power (North and Weingast 2009). But China cannot simply repeat Western history. It must find its own way of developing a viable and independent legal system with secure rights.

We suggest a devolution of much more of the commercial legal system and the entire matter of corporate registration to the provinces (including current Special Administrative Regions, Autonomous Regions and Direct-Controlled Municipalities). A typical Chinese province has a population in the tens of millions. Within limits, and subject to the supremacy of national law, provincial legislatures should have latitude to experiment with variations in commercial and corporate law. This would result in some inter-provincial competition to host the more dynamic and productive Chinese enterprises. In turn, indigenous corporations would take into account the viability and security of the provincial legal systems when choosing a province in which to register.

The government of the People's Republic of China might also consider introducing at the provincial level a further measure of local democracy. Many village committees in rural areas are already elected democratically, although the procedures are sometimes abused by corrupt local officials. The introduction of democratic provincial government would reinforce the relative autonomy of provincial legislatures and encourage local private business. On the other hand, the experience of the former Soviet-bloc countries shows that the introduction of political democracy does not always result in political stability or improved governance (Weingast 2005, Hodgson 2006). Given that China has no experience of developed democratic institutions, the introduction of democracy at the provincial level might best be staggered and experimental.

With the abolition of the hukou system, urban and rural resisdents would have equal rights to welfare, pensions, and education. The demands on the health and education systems bare likely to increase as a result of demographic shifts outlined in section 1 . The tax system would have to be reformed and expanded. Alongside the development and equalisation of the welfare and education systems, there is a need for adequate provision of legal aid. Without recourse to legal advice and representation, leasehold and property rights will be insufficiently secure. This is especially important for rural workers protecting their land-use rights from confiscation or encroachment by corrupt or over-zealous local officials.

A further possibility would be to grant the provinces some discretion over the provision of welfare, education and legal aid. Insofar as inter-provincial migration is feasible for families and individuals, this would create some competition between provinces to provide better conditions to attract workers. 


\section{Conclusion}

No two capitalist systems are alike. Each bears the marks of its own unique history. China has to find its own path of development and it should not aim to imitate Western (or more specifically, Anglo-American) institutions in all their detail. But China can learn from the institutional experiences of other capitalist countries and the histories of their development.

Institutional stasis is not an option. China must develop a full programme of institutional reforms, allowing some scope for provincial and other local experiments. Otherwise it will face huge problems and its development will be arrested. China needs to develop adequate welfare and pension provision for an ageing population, a country-wide and inclusive education system to create a larger pool of skilled labour for a modern knowledge-intensive economy, and an adequate system of corporate law to protect and encourage indigenous private business.

In developing a modern market economy we are not suggesting that China surrenders to laissez faire. Much of China's economic success is attributable to the strategic role of the state in the economy, alongside the development of incentives for enterprise. As Peter Nolan (2004, p. 166) remarks: 'In seeking for a moral framework to guide its development, China can look back to its long history of state activity to try to make the market serve common social purposes.'

There is little doubt that in a few years China will become the largest economy in the world in terms of overall GDP. But growth rates in excess of nine per cent per annum cannot be sustained. The institutional and demographic problems that we have raised here suggest that growth may slow down even more rapidly than anticipated. Given these problems, one possible scenario is that China quickly slows down to an annual growth rate in the order of two to four per cent. Its growth rate would then be close to that found in developed countries. In this case it will have great difficulty - even after several decades - approaching levels of GDP per capita that are found in the developed world. It will remain the largest in terms of GDP, but a much less impressive laggard in terms of GDP per capita.

\section{References}

Allen, Franklin, Qian, Jun and Qian, Meijun (2008) 'China's Financial System: Past, Present, and Future', in Rawski, Thomas G. and Brandt,Loren (eds) (2008) China's Great Economic Transformation (Cambridge and New York: Cambridge University Press), pp. 506-568.

BBC News (2011) 'China Village Protest: Wukan Mediator Xue Jinbo Mourned', 16 December. http://www.bbc.co.uk/news/world-asia-china-16219870. Retrieved 29 December 2011.

Bian, Yanjie, Lin Nan and Zhou, Xueguang (eds) (2011) The China Society Yearbook (Chinese Academy of Social Sciences and Leiden: Brill).

Boisot, Max H. and Child, John (1996) 'From Fiefs to Clans and Network Capitalism: China's Emerging Economic Order', Administrative Science Quarterly, 41(4), pp. 600-28. 
Boyreau-Debray, Genevieve and Shang-Jin Wei (2005) 'Pitfalls of a State-Dominated Financial System: The Case of China', US National Bureau of Economic Research Working Paper 11214.

Central Intelligence Agency (2011) 'The World Factbook', https://www.cia.gov/library/publications/the-world-factbook/geos/ch.html. Retrieved 24 December 2011.

Chan, Kam Wing and Li Zhang (1999) 'The Hukou System and Rural-Urban Migration in China: Processes and Changes', China Quarterly, 160, pp. 818-855.

Chan, Kam Wing and Will Buckingham (2008) 'Is China Abolishing the Hukou System?', China Quarterly, 195, pp. 582-606.

China Human Resources and Social Security Publishing Group (2011) Pension Development Report of China (Beijing: China Human Resources and Social Security Publishing Group).

China Labour Bulletin (2011) 'Migrant Workers on China', http://www.chinalabour.org.hk/en/node/100259. Retrieved 28 December 2011.

Chow, Gregory C. (2011) China as a Leader of the World Economy (Singapore: World Scientific Publishing).

Chow, Gregory C. and Kui-Wai Li (2002) 'China's Economic Growth: 1952-2010', Economic Development and Cultural Change, 51(1), October, pp. 247-256

Clarke, Donald C. (2005) 'How Do We Know When an Enterprise Exists? Unanswerable Questions and Legal Polycentricity in China', Columbia Journal of Asian Law, 19(1), pp. 50-71.

Constitution of the People's Republic of China (2004) (Revision of 2004). http://english.peopledaily.com.cn/constitution/constitution.html. Retrieved 27 December 2011.

De Soto, Hernando (2000) The Mystery of Capital: Why Capitalism Triumphs in the West and Fails Everywhere Else (New York: Basic Books).

Du, Luosha, Ann E. Harrison, and Gary H. Jefferson (2011) 'Do Institutions Matter for FDI Spillovers? The Implications of China's "Special Characteristics", NBER Working Paper 16767.

Economist (2005) 'Protests in China: The Cauldron Boils', The Economist, 29 September. http://www.economist.com/node/4462719. Retrieved 29 December 2011.

Economist (2012) Special Report - State Capitalism: The Visible Hand (London: The Economist).

Feyrer, James (2007) 'Demographics and Productivity', Review of Economics and Statistics, 89(1), February, pp. 100-109.

Fogel, Robert (2010) ‘ $\$ 123,000,000,000,000$ : China’s Estimated Economy by 2040. Be Warned', Foreign Policy, January-February, http://www.foreignpolicy.com/articles/2010/01/04/123000000000000. Retrieved 1 February 2012.

He, Zengke (2000) 'Corruption and Anti-Corruption in Reform China', Communist and PostCommunist Studies, 33, pp. 243-70. 
Hodgson, Geoffrey M. (2006) 'Institutions, Recessions and Recovery in the Transitional Economies', Journal of Economic Issues, 40(4), December, pp. 875-94.

Hodgson, Geoffrey M. and Jiang,Shuxia (2007) 'The Economics of Corruption and the Corruption of Economics: An Institutionalist Perspective', Journal of Economic Issues, 41(4), December, pp. 1043-61.

Huang, Jingjin (2011) 'Investigation in Wukan', Global Times, 23 December. http://www.webcitation.org/648VxXfp6. Retrieved 29 December 2011.

Huang, Yasheng (2008) Capitalism with Chinese Characteristics: Entrepreneurship and the State (Cambridge and New York: Cambridge University Press).

Koopman, Robert, Zhi Wang, and Shang-jin Wei (2008) 'How Much of Chinese Exports is Really Made in China? Assessing Foreign and Domestic Value-Added in Gross Exports', US International Trade Commission Working Paper No, 2008-03-B, http://www.usitc.gov/publications/332/working_papers/ec200803b_revised.pdf

Kwong, Julia (1997) The Political Economy of Corruption in China (Armonk NY: M. E. Sharpe).

Land Administration Law of the People's Republic of China (2004) (Revision of 2004) http://www.fdi.gov.cn/pub/FDI_EN/Laws/GeneralLawsandRegulations/BasicLaws/P0200 60620320252818532.pdf. Retrieved 27 December 2011.

Lu, Xiaobu (2000) 'Booty Socialism, Bureau-preneurs, and the State in Transition: Organizational Corruption in China', Comparative Politics, 32(3), April, pp. 273-94.

Manion, Melanie (1996) 'Corruption by Design: Bribery in Chinese Enterprise Licensing', Journal of Law, Economics, and Organization, 12(1), April, pp. 167-95.

Modigliani, Franco and Cao, Shi Larry (2004) 'The Chinese Savings Puzzle and the LifeCycle Hypothesis', Journal of Economic Literature, 42(1), March, pp. 145-70.

National Bureau of Statistics of China (2004) China Economic Census Yearbook 2004 (Beijing: China Statistics Press).

National Bureau of Statistics of China (2006) China Industrial Economics Statistics Yearbook 2006 (Beijing: China Statistics Press).

National Bureau of Statistics of China (2010) China Industrial Economics Statistics Yearbook 2010 (Beijing: China Statistics Press).

National Bureau of Statistics of China (2011) China Statistical Yearbook 2011 (Beijing: China Statistics Press). Also http://www.stats.gov.cn/tjsj/ndsj/2010/indexeh.htm. Retrieved 5 December 2011.

Naughton, Barry (2007) The Chinese Economy: Transitions and Growth (Cambridge MA: MIT Press).

Nolan, Peter (2004) China at the Crossroads (Cambridge UK and Maldon MA: Polity Press).

Nolan, Peter and Wang Xiaoqiang (1999)' Beyond privatization: Institutional Innovation and Growth in China's Large State-Owned Enterprises', World Development, 27(1), January, pp. 169-200.

North, Douglass C., Wallis, John J. and Weingast, Barry R. (2009) Violence and Social Orders: A Conceptual Framework for Interpreting Recorded Human History (Cambridge: Cambridge University Press). 
OECD (2009) 'OECD Rural Policy Review: China', http://www.oecd.org/document/33/0,3746,en_2649_33735_42230497_1_1_1_1,00.html. Retrieved 12 January 2012.

OECD (2011) 'China's Emergence as a Market Economy: Achievements and Challenges', OECD contribution to the China Development Forum, 20-21 March, Beijing. www.oecd.org/dataoecd/27/17/47408845.pdf. Retrieved 12 January 2012.

Sicular, Terry, Yue Ximing, Björn Gustafsson, and Li Shi (2007) 'The Urban-Rural Income Gap and Inequality in China', Review of Income and Wealth, 53(1), March, pp. 93-126.

Song, Zheng, Storesletten, Kjetil, and Zilibotti, Fabrizio (2011) 'Growing Like China', American Economic Review, 101(1), February, pp. 202-241.

Sull, Donald N. (2005) Made in China: What Western Managers Can Learn from Trailblazing Chinese Entrepreneurs (Boston: Harvard Business School Press).

UN Data (2012) United Nations Statistics Division. http://data.un.org/Data.aspx?d=PopDiv\&f=variableID\%3A68. Retrieved 10 Jan 2012.

US Census Bureau (2011) 'International Data Base', http://www.census.gov/population/international/data/idb/country.php. Retrieved 23 Dec 2011.

Wang, Zhenyao (1998) 'Village Committees: The Basis for China's Democratization', in Vermeer, Eduard B., Frank N. Pieke and Woei Lien Chong (eds) (1998) Cooperative and Collective in China's Rural Development: Between State and Private Interests (Armonk, NY: M. E. Sharpe), pp. 239-256.

Wang, Zhi and Shang-Jin Wei (2008) 'What Accounts for the Rising Sophistication of China’s Exports?’ US National Bureau of Economic Research, Working Paper 13771.

Wank, David L. (1999) 'Producing Property Rights: Strategies, Networks, and Efficiency in Urban China's Nonstate Firms', in Oi, Jean C. and Walder, Andrew G. (eds) (1999) Property Rights and Economic Reform in China (Stanford: Stanford University Press), ch. 11, pp. 248-72.

Weingast, Barry R. (2005) 'The Constitutional Dilemma of Economic Liberty', Journal of Economic Perspectives, 19(3), Summer, pp. 89-108.

Wikipedia (2011) 'Protests of Wukan', http://en.wikipedia.org/wiki/2011_Lufeng_city_riot. Accessed 29 December 2011.

Zhang, Kevin Honglin and Shunfeng Song (2003) 'Rural-Urban Migration and Urbanization in China: Evidence from Time-Series and Cross-Section Analyses', China Economic Review, 14, pp. 386- 400 .

Zheng, Lifei (2011) 'Wen Urges Protection for Farmer Rights, Stop to Land Grabs', Bloomberg Businessweek, 28 December. http://www.businessweek.com/news/2011-1228/wen-urges-protection-for-farmer-rights-stop-to-land-grabs.html. Retrieved 29 December 2011.

Zhou, Kate Xiao (1996) How the Farmers Changed China (Boulder, CO: Westview Press). 